\title{
Quality of Working Life among Nurses at a General Hospital in Malaysia
}

\author{
Nurmuslimah Kamilah abdullah \\ Faculty of Business and Management \\ Univesiti Teknologi MARA Cawangan Terengganu \\ Terengganu, Malaysia \\ nurmuslimah@tganu.uitm.edu.my \\ Najah Lukman \\ Faculty of Business and Management \\ Univesiti Teknologi MARA Cawangan Terengganu \\ Terengganu, Malaysia \\ najah@tganu.uitm.edu.my
}

\author{
Ruzaidah Sulong A. Rashid \\ Faculty of Business and Management \\ Univesiti Teknologi MARA Cawangan Terengganu \\ Terengganu, Malaysia \\ ruzai019@tganu.uitm.edu.my \\ Yau'mee Hayati Mohamed Yusof \\ Faculty of Business and Management \\ Univesiti Teknologi MARA Cawangan Terengganu \\ Terengganu, Malaysia \\ yaumee555@tganu.uitm.edu.my
}

\author{
Masthura Annuar \\ Faculty of Business and Management \\ Univesiti Teknologi MARA Cawangan Terengganu \\ Terengganu, Malaysia \\ maszannuar@gmail.com
}

\begin{abstract}
General Hospital in Malaysia, focusing on the nurses as the unit of analysis. Job Content, Job Context and Personal Life were parsimoniously selected as the independent variables towards Quality of Working Life (QWL) among nurses at a General in Malaysia. There are there objectives of this study which are to describe the level of QWL among nurses at a General in Malaysia; to identify the relationship between job context, job content and personal life with QWL among nurses, and to identify how well the job context, job content and personal life explain the variance of QWL among nurses. It was found that averagely the respondents elicited towards agree answer for all items measuring the QWL concept. However, since there were obvious frequencies of disagree responses; it is advisable to the managerial level to give attention in scrutinizing each item. Job Content, Job Context and Personal Life have significant relationship with QWL among nurses at a General in Malaysia, and the combination of these three independent variables made up $55 \%$ of contributing factor towards the dependent variable. Out of the three independent variables, only Job Content and Job Context were significant. Thus, management of the General Hospital should give special attention to the Job Context and Job Content aspect in improving the QWL.
\end{abstract}

Keywords-quality of work life; job content; job context; personal life

\section{INTRODUCTION}

Quality of working life (QWL) describes people working life, where they are going to have a day-to-day life at their workplace. Since most of the workers are going to face the same nature of routine in performing their work, human limitation may set a parameter towards their working life.
Nurse is an occupation performs in stressful working environment; therefore their QWL is worth to be focused on.

Hospital is a convenient place where patients will get various services from doctor or nurses. Even though, the nurses went through lots of training program, complaint may arise from patients. It is supported by McDougall and Levesque (2000) in [1] stated that, the hospital will face a problem if their staffs deliver poor quality of service that lead to customer dissatisfactions. Bolch (2008) in [2] highlighted that sometimes, staffs at experiencing "unsafe working conditions, back injuries, long hours and mandatory overtime". Ellis and Pompli (2002) in [3][12] identified that the problems that cause job dissatisfaction on QWL are poor working environment, non-recognition of work, shift work, no involvement in decision making, lack of deliver a good quality care, unable balance of work and family, low relationship with supervisor and colleagues, role conflict and lack of skill. All of these lead to barriers for achievement QWL on employees.

Studies among nurses in the USA, Iran and Taiwan were found that, problem that affect QWL is the lack of work balance because of rotating schedules where they were unable to have work balance with family needs [4]. On top of that the major problem occur when the female nurses need to balance between work and family needs such as child care in case of sickness, managing home stress and work stress, special child needs, exhaustion from work where effect home needs and conditions at home where can affecting quality care and work productivity [5]. Further at Ogun State tertiary educational institutions, the problem that cause of job dissatisfaction because of unpaid salary, late payment of monthly salaries and allowances [6]. 
Since QWL is very important in making sure the best service can be delivered to the patient, it is paramount to scrutinize the factors that may trigger QWL among nurses.

\section{A. Research Questions}

RQ1: What is the level of QWL among nurses at a General in Malaysia?

RQ2: What is the relationship between job context, job content and personal life with QWL among nurses at a General in Malaysia?

RQ3: How well the job context, job content and personal life explain the variance of QWL among nurses at a General in Malaysia?

\section{B. Hypothesis}

H1: There is a relationship between job context and QWL among nurses at a General Hospital in Malaysia

$\mathrm{H} 2$ : There is a relationship between job content and QWL among nurses at a General Hospital in Malaysia

H3: There is a relationship between personal life and QWL among nurses at a General Hospital in Malaysia

H4: Job context, job content, and personal life are predictors in explaining QWL among nurses at a General Hospital in Malaysia

\section{LITERATURE REVIEW}

\section{A. Quality of Woking Life}

Ryan (1995) in [7] stated that, in the year 1972, the first concept of quality of working life (QWL) has been introduced at the International Labours Relation Conference in New York. The purpose of the concept is to establish a good work condition for the worker that call as "Human Working Life". QWL also can be defined as a Person's life which means person's feeling towards work including working condition, rewards and benefits, job security, organizational and interpersonal relations [8]. All of these concern to improve life at work and life outside work. Thus, QWL is something special that can influence individual behavior, because its show a connection with individual's feeling. Many benefits obtained when assigning QWL because it lead to happiness and employee's satisfaction and automatically award opportunity to organization and employees to accumulating productivity [9].

Nayeri, et al. (2011) in [4] conducted a study to investigate the relationship between QWL and productivity. Based on result found that $3.6 \%$ nurses from $61.4 \%$ were satisfied with their work and the rest is stated as low productivity so the manager needs to apply another concept to achieve employee productivity in QWL. Cummings and Worley (2005) in [3] stated that, there are several concept of QWL that may affect employee's productivity and job satisfaction which are right and esteem needs, reward system, employee involvement and physical work environment. These show that QWL is very critical issue to be taken care.

The European Foundation for the Improvement of Living Condition (2002) in [3], describe QWL as a multi-dimensional construct that include variety factors such as job involvement, motivation, job satisfaction, productivity, safety and health, job security, job competence, work balance between professional and personal life. It was supported by another definition, where QWL is defined as multi-dimensional concept where cover a few criteria such as communication, health and safety, job security, promotions, pay and benefits, physical work environment, teamwork, autonomy, employees' feelings about the job content, participation in decision-making, colleagues and managers support and work-life balance [13]. Further Zare et al. (2012) in [10], described work life balance as work life atmosphere, healthy work condition, ergonomics, distance between workplace and home, opportunity for celebrate religious ceremonies and ideal working hours.

\section{B. Job Context}

Job context refers to the situation where work being performed and it can be identified through job analysis such as a relationship with supervision or colleagues, authority, working conditions, judgement, personal contact and physical and mental demands [11]. In this study, there are few elements under job context to be focused on such as work environment, compensation and benefit, relationship at workplace and religious and culture that can affect worker. Relationship with peers, work environment and management procedure are elements can effect on nurses work context [4]. This is because mostly these variables always are used in many literatures in work sector as mentioned by Janakiraman, Parish and Berry (2011) and Griffin, Patterson, and West (2001) in [2].

\section{Work Environment}

Work environment can give positive and negative perception [14]. The positive perception is when employee feel appreciated so they feel happy to come work meanwhile the negative perception is when they feel under appreciated. This statement also supported by Hasket et al. (1997) in [3], a positive feeling will appear when employees satisfied with the work environment that shows through happiness in work life. Milutinovic et al., (2012) in [15] mentioned that nurses have a unique working environment where they involve more to life and death situations, extra working hours, rotate work, supportive colleagues and etc. Sometimes nurses need to work overtime because they often face with an emergency case. Work overtimes are needed in working environment because it is something crucial and desirable to organizations in helping meet demands especially for QWL in the hospital sector [16]. Furthermore, the reality at a General Hospital is, there are too many patients that need to be cared off from time to time and sometimes nurses need to work a double-shift to cover duties when shortages of staff happened.

\section{Compensation and Benefit}

Mirvis and Lawler (1984) in [17] highlighted that, there are basic elements of QWL which is fair payment. Kotze, (2005) in [18] stated that organizations must have proper policies (compensation and benefit) for employee because when employee feel satisfied with the compensation management, it will influence to employee's loyalty and trust. It shows that 
employee benefit is a crucial thing because it can make employees feel satisfied with their work and it can increase their desire to keep working in the organization. Furthermore, rewards or compensation and benefits and working conditions are part of person's feeling in the quality of working life as mentioned by Guest (1979) in [19].

\section{Relationship at Workplace}

Relationship among colleagues at a workplace is important because it leads to personal contact where it can build strong teamwork. A good relationship helps in solving any kind of problem because good relation can enhance spirit towards teamwork [10]. In the year 1970's, Robert Greenleaf has marked that leaders has a big power where they can be the role model in developing relationship among team member and also can motivate them [20]. This is because a leader is a source of reference among followers. It was supported by Chandrasekar (2011) in [21], supportive supervisor is the main role in encouraging employees when doing job and supervisor's support also importance in building employee's self-motivation and positive relations. Other than that, Brooks \& Anderson (2004) in [5] mentioned that quality at workplace can be reached by building affiliation between colleagues so from that mutual understanding and good communication can be boost among staff in workplace. This is because employee and organization have the interrelated objectives, which are all employee wants quality, and comfortable work place meanwhile every organization wants more outputs in comparison of less input [8], both of them show a correlation where they need to create a good relationship between employees and working environment.

\section{Religious and Culture}

According to Datta (1999) in [22], QWL similar with the quality of life where individual implement educational, cultural, commercial and religious in the workplace. As we know our country have various races such as Malay, Indian, Chinese, and others and they have their own religious celebration. For example Christmas Day, Hari Raya Aidilfitri, Deepavali, Chinese New year and others. Result of s study conducted by [22] shows that $28.33 \%$ respondents strongly agreed that the organization celebrates national and regional festivals to have fun at the workplace. Further, Zare, et al. (2012) in [10][23] agreed that religious ceremonies included in work life balance.

\section{Job Content}

Zare et al. (2012) in [10][23] described job content as opportunity of development, teamwork, autonomy, responsibility in work, rich and challenging work, meaningful work and talented in work. Reference [10] also cited Connell and Hannif (2009) where, job content is one of the factors of QWL and its mostly refer to the individual who can control the factors by themselves such as skills, responsibility and effort. Job content also described as employee feedback, significant work, multi-task and autonomy [24].

\section{Skills}

Firstly, skills are important in QWL especially for health care sector because this sector needs a capable worker to ensure they can give a good service and performance. It supported by Hall (n.d) in [25] stated that, to become productive and talented nurses, the nurses must maintain and gain the QWL in the work setting. One of ways to improve the skill of employee is job rotation; it is because it can measure individual knowledge, skill and capability of employees where the worker will be assigned to work in different situation or position in time-to-time [26]. When the employee does multijob they can develop a new skill and gain knowledge from a different position [27]. On top of that, Bei (2009) in [28] highlighted that job rotation is an effective training to develop more job skills and when an employee doing a different job it can increase their desire and motivation toward work, because training programs are the best method in achieving goals [12]. Benedicta (2010) in [29] supported that, the training process help to improve employee knowledge, skills, ability, competencies and behaviour so it proves that training gives a large contribution towards organization development and employees performance improvement.

\section{Employee Advancement}

According to Certo (2004) in [30], QWL allows opportunity to employee to make decision, which can affect their work situation where the greater the opportunity given to the employee to make decision, the higher the QWL experience. Therefore, it can give an advantage to employee advancement because when the workers actively participate in decisionmaking process, they may feel more accountable in performing their work. The involvement of employees in decision-making process will promote employee empowerment. Employee empowerment is the practice of enriching jobs, so that the added responsibility and authority id moved to the lowest level of employees where they also able to make a decision [31]. When employees have the power to voice out what they think so they will feel appreciated and valuable, thus it can increase employee's commitment and performance.

\section{Job Performance}

Nurses give large contribution in hospital sector while doing their duties and they must act confident when making decision. Factors of the quality of employed life such as advancement chance, enough revenue, development of human potentials, order in work, overall work atmosphere and social unity give positive relation with performance [32]. QWL was found positively and significantly related to employee job performance which directly affects the organizational performance [33]. Thus, the nurses must have variety of skills that really help in performing their job, where training and development program is essential towards quality of job performance in organizations [34]. Performance is a degree of fulfillment task that form an individual in job where it illustrate how well individual complete his or her job demands and when employee perform a job well so they will feel more satisfied 
and it will increase commitment towards job and organization [35].

\section{Job Intrinsic}

Kreitner (1995) and Grafham et al. (2004) in [36] define job intrinsic as a psychologically process that represent the behaviour of an individual, which means the internal desire of individual in order to accomplish his or her job successfully. Therefore, job intrinsic is related with job characteristic because it shows individual behaviour in performing his or her job. Based on Hackman and Oldham's Job Characteristics Model (1976) in [37], there is five core job characteristics which are skills variety, task identity, task significance, autonomy, and feedback and all of them lead to three "critical psychological states". Variables affecting job satisfaction in QWL in the nursing sector is related to intrinsic work values where the satisfaction of nursing work appear when they feel satisfied because they are able to complete the task during working hours [38]. This is because they can prove to the organization that they are capable in doing their job and honored responsibility toward their job.

\section{Personal Life}

Even though personal life seems like an issue beyond the work setting, its relevant to be discussed in QWL because personal life problem might affect on how the workers live their live at work. Adhikari and Gautam (2010) in [7] said that there are few things that emphasis on personal life but the problem was be solved by having QWL concept in organizations. Cherg.S (n.d) in [8] mentioned that high QWL tend to be a positive impact on personal life and an opportunity for an employee in making a decision as well as an acceptable level of physical comfort. A balance between both in career and personal life are needed because, sometimes the job satisfaction, external environment and personal life can affect QWL [18]. Reference [18] cited from Che Rose et al. (2006) as QWL can be influenced by a few elements and one of them are the relationship between on the job and off the job life.

\section{Leisure}

In fact, personal life is important in QWL because the good personal life can give positive impact towards employees' life. However, it also can give negative impact if employee too focus on work until they get stress and then influence their personal life. It supported by Edwards \& Rothbard (2000) in [39], if the employee unable to balance demands of work and personal life it can lead to stress and affects the workforce. So to ensure the employee does not too involve in work stress they must join some program or activity. Several studies (Coleman, 1993; Heintzman \& Mannell, 2003; Iwasaki, MacKay, and Mactavish, 2005; Iwasaki \& Mannell, 2000) in [40] stated that there has been researching which suggests "leisure" as an effective way to reduce work stress and at the same time it balance within employee work and personal life. When the organization provides leaves and time off for recreational activities it can lead to a quality work environment which indirectly effect to QWL [19]. On top of that, agreement was given to the fact that leisure is a good strategy that can be applied at healthcare organization to improve work life [40]. This is because leisure can be described as a therapy for reducing stress and having the ideal work balance. There are few examples for leisure activity which are yoga, massage and relaxation, and socialize with a co-worker.

\section{Family Life}

Rapoport and Rapoport (n.d) in [3] mentioned that family life also can influence personal life. In fact, family and work are important in life balance because the important factor of QWL is a family's psychological support where family life has the power to give the positive impact towards job satisfaction and career achievement. Further, the individual who contribute time and energy at work also need to balance on their life too such as maintaining family and career balance [3]. In personal life individual should have a balanced relationship between working time and time to spend with family on recreational activities because it leads to balance work life [41]. When more time was spent at work it may affect time to be spent at family, leisure or other activities [42]. Therefore, it is crucial in nursing workforce to achieve work-family life balance [43]. This is because work family balance can be described as the extent to which an individual is equally engaged in and equally satisfied with his or her work role and family role [44]. Greenhans and Allen (2006) in [42] stated that individual's effectiveness and satisfaction in work and family roles are compatible with the individual's life priorities.

\section{METHODOLOGY}

The population of the study was 1100 nurses at a General in Malaysia. The population consisted of nurses in grade U42 (2 nurses), grade U41 (5 nurses), grade U36 and U29 (940 nurses and lastly grade U19 and U24 (163 nurses). The researcher decided to use non-probability sampling which is convenience sampling in triggering the quick data collection technique. 350 questionnaires were distributed at $92 \%$ of response rate (323 completed questionnaires).

\section{RESULTS AND DISCUSSION}

\section{A. Demographic Profile}

Table I describes the demographic profile of the respondents in term of age, gender, marital status, educational level, grade and working experience. 
TABLE I. RESPONDENTS' PROFILE

\begin{tabular}{|c|c|c|c|}
\hline Demographic & Category & $\mathrm{N}$ & 96 \\
\hline \multirow{6}{*}{$\begin{array}{c}\text { Variable } \\
\text { Age }\end{array}$} & & & \\
\hline & below 20 years & 1 & 03 \\
\hline & 21 to 30 years & 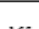 & 0 \\
\hline & 31 to 50 years & 103 & 21.1 \\
\hline & & 157 & 48.6 \\
\hline & Total & 333 & 100 \\
\hline \multirow[t]{3}{*}{ Gender } & male & 7 & 2.2 \\
\hline & female & 316 & 97.8 \\
\hline & Total & 323 & 100 \\
\hline \multirow[t]{3}{*}{ Status } & Single & 183 & 56.7 \\
\hline & Married & 140 & 43.3 \\
\hline & Total & 323 & 100 \\
\hline \multirow{4}{*}{ Education level } & SPM & 62 & 19.2 \\
\hline & Diploma & 173 & 53.6 \\
\hline & Bachelor Degree & 88 & 27.2 \\
\hline & Total & 323 & 100 \\
\hline \multirow[t]{8}{*}{ Grade } & $\mathrm{U} 42$ & 2 & 0.6 \\
\hline & $\mathrm{U} 41$ & 5 & 1.5 \\
\hline & U36 & 119 & 36.8 \\
\hline & U32 & 75 & 23.2 \\
\hline & U29 & 61 & 18.9 \\
\hline & U24 & 46 & 14.2 \\
\hline & U19 & 15 & 4.6 \\
\hline & Total & 323 & 100 \\
\hline \multirow[t]{5}{*}{ Working Experience } & $0-5$ years & 79 & 24.5 \\
\hline & $6-10$ years & 87 & 26.9 \\
\hline & $11-15$ vears & 143 & 44.3 \\
\hline & $16-20$ years & 14 & 4.3 \\
\hline & Total & 323 & 100 \\
\hline
\end{tabular}

\section{B. Goodness of Measure}

Table II shows the reliability results of each variable involved in the study, which is very good. Since the Cronbach's Alpha values scored more than 0.70, thus it is considered highly reliable for further analysis [45], where items developed for each concept are consistent and stable. However, since there is an argument where values above 0.9 are not desirable where they indicate that all the indicators variables are measuring the same phenomenon [46], the correlations among independent variables in Table IV would support the decision in continuing for further analysis.

TABLE II.

LIABILITY TEST

\begin{tabular}{|c|c|c|}
\hline Variable & Total item & $\begin{array}{c}\text { Cronbach's } \\
\text { Alpha }\end{array}$ \\
\hline QWL & 8 & .943 \\
\hline Job Context & 26 & .967 \\
\hline Job Content & 26 & .975 \\
\hline Personal Life & 11 & .958 \\
\hline
\end{tabular}

\section{The level of $Q W L$ among nurses}

Table III shows the descriptive analysis of QWL in answering the research question 1 . There were 8 questions developed in operationalizing the QWL concept. Averagely, all items scored between 4.60-4.85 (elicited agree response) with standard deviation in a range of 1.190-1.365. However the score per scale column shows at least there is $12 \%$ of respondents elicited disagree answer (1=extremely disagree, $7=$ extremely agree). For example, there are 39 disagree responses with a statement of "I enjoy coming to work". Meaning that 39 nurses feel not enjoy to come to work.

TABLE III

DESCRIPTIVE STATISTICS OF QWL

\begin{tabular}{|c|c|c|c|c|c|c|c|c|c|c|c|c|c|}
\hline \multicolumn{14}{|c|}{ Descriptive Statistics } \\
\hline & \multirow[t]{2}{*}{$\mathrm{N}$} & \multirow[t]{2}{*}{ Min } & \multirow[t]{2}{*}{ Max } & \multirow[t]{2}{*}{ Mean } & \multirow[t]{2}{*}{\begin{tabular}{c|} 
Std. \\
Deviation
\end{tabular}} & \multirow[t]{2}{*}{ Variance } & \multicolumn{7}{|c|}{ Score per scale } \\
\hline & & & & & & & 1 & 2 & 3 & 4 & 5 & 6 & 7 \\
\hline $\begin{array}{l}\text { Tenjoy coming to } \\
\text { work }\end{array}$ & 323 & 1 & 7 & 4.85 & 1.208 & 1.460 & 2 & 8 & 29 & 83 & 99 & 78 & 24 \\
\hline I like my job & 323 & 1 & 7 & 4.85 & 1.356 & 1.839 & 3 & 10 & 41 & 73 & 88 & 69 & 39 \\
\hline $\begin{array}{l}\text { I feel satisfied } \\
\text { working in my } \\
\text { department }\end{array}$ & 323 & 2 & 7 & 4.60 & 1.306 & 1.706 & 0 & 18 & 42 & 99 & 86 & 47 & 31 \\
\hline $\begin{array}{l}\text { If feel significant } \\
\text { working in this } \\
\text { organization }\end{array}$ & 323 & 1 & 7 & 4.70 & 1.190 & 1.416 & 3 & 6 & 37 & 97 & 93 & 70 & 17 \\
\hline $\begin{array}{l}\text { Conditions in the } \\
\text { job allows me to } \\
\text { be productive }\end{array}$ & 323 & 1 & 7 & 4.80 & 1.331 & 1.772 & 2 & 12 & 41 & 77 & 87 & 71 & 33 \\
\hline $\begin{array}{l}\text { The environment } \\
\text { in this } \\
\text { organization } \\
\text { supports a balance } \\
\text { between work and } \\
\text { personal life }\end{array}$ & 323 & 1 & 7 & 4.74 & 1.392 & 1.938 & 3 & 17 & 34 & 91 & 80 & 58 & 40 \\
\hline $\begin{array}{l}\text { I am satisfied with } \\
\text { the working } \\
\text { condition } \\
\text { provided by the } \\
\text { organization }\end{array}$ & 323 & 1 & 7 & 4.60 & 1.365 & 1.862 & 5 & 18 & 39 & 84 & 103 & 42 & 32 \\
\hline $\begin{array}{l}\text { Quality of } \\
\text { working life is the } \\
\text { organization's } \\
\text { work culture }\end{array}$ & 323 & 1 & 7 & 4.78 & 1.286 & 1.655 & 6 & 6 & 28 & 99 & 87 & 67 & 30 \\
\hline Valid N (listwise) & 323 & & & & & & & & & & & & \\
\hline
\end{tabular}

\section{The relationship between job context, job content and personal life with $Q W L$ among nurses}

Table IV shows the results for Pearson Correlation analysis. All relationships between Job Context $(\mathrm{r}=0.381)$, Job Content $(\mathrm{r}=0.705)$, and Personal Life $(\mathrm{r}=0.569)$ are significant at 0.01 towards $\mathrm{QWL}(\mathrm{p}=0.000)$. Therefore hypothesis 1,2 , and 3 are supported. Assessing relationships among independent variables show that all $\mathrm{r}$-values are less than 0.9 . Since multicollinearity exists when the independent variables are highly correlated ( $\mathrm{r}=0.9$ and above) [47], thus the issue of measuring the same phenomenon in measuring the reliability is solved.

TABLE IV

PEARSON CORRELATION

\begin{tabular}{|c|c|c|c|c|c|}
\hline \multicolumn{6}{|c|}{ Correlations } \\
\hline & & Mean & Mean & Mean & Mean \\
\hline & & QWL & J.Ctx & J.Ctn & PL \\
\hline \multirow[t]{3}{*}{ QWL } & Pearson Correlation & 1 & $.381^{* *}$ & $.705^{* *}$ & $.569^{*+*}$ \\
\hline & Sig. (2-tailed) & & .000 & .000 & .000 \\
\hline & $\mathrm{N}$ & 323 & 323 & 323 & 323 \\
\hline \multirow[t]{3}{*}{ J.Ctx } & Pearson Correlation & $.381^{* *}$ & 1 & $.226^{* *}$ & $.195^{* *}$ \\
\hline & Sig. (2-tailed) & .000 & & .000 & .000 \\
\hline & $\mathrm{N}$ & 323 & 323 & 323 & 323 \\
\hline
\end{tabular}


Table IV. Cont

\begin{tabular}{|l|c|r|r|r|r|}
\hline J.Ctn & Pearson Correlation & $.705^{* *}$ & $.226^{* *}$ & 1 & $.796^{* *}$ \\
\hline & Sig. (2-tailed) & .000 & .000 & & .000 \\
\hline & $\mathrm{N}$ & 323 & 323 & 323 & 323 \\
\hline PL & Pearson Correlation & $.569^{* *}$ & $.195^{* *}$ & $.796^{* *}$ & 1 \\
\hline & Sig. (2-tailed) & .000 & .000 & .000 & \\
\hline & $\mathrm{N}$ & 323 & 323 & 323 & 323 \\
\hline & $* * *$ Correlation is significant at the 0.01 level (2-tailed). \\
\hline \multicolumn{6}{|c|}{}
\end{tabular}

\section{E. The influence of job context, job content and personal life} in explaining the $Q W L$

Table $\mathrm{V}$ indicates that $55 \%$ of the identified independent variables explain the variance QWL among nurses at a General Hospital in Malaysia $(\mathrm{p}=000, \mathrm{~F}=129.507)$. Therefore hypothesis 4 is supported.

Two independent variables were found to be significant in influencing the QWL among nurses at a General Hospital in Malaysia namely: Job Context $(\mathrm{p}=000)$ and Job Content $(\mathrm{p}=0.000)$. On top of that, Job Content is the strongest predictor that can contribute to the QWL among nurses at a General Hospital in Malaysia $(\beta=0.645)$. In opposite, Personal Life is found to be insignificant variable in explaining QWL among nurses at a General Hospital in Malaysia because the p-value is more than 0.05 ( $\mathrm{p}=0.873)$.

The tolerance and VIF value for each independent variable indicates the multicollinearity assumption is not violated. It is because the tolerance values are more than 0.10 and the VIF values are less than 10 (Pallant, 2010). Pallant urges that if the results exceeded the recommended values, we should seriously consider removing one of the highly intercorrelated independent variables from the model.

TABLE V.

MULTIPLE REGRESSION

\begin{tabular}{|c|c|c|c|c|c|c|c|}
\hline \multicolumn{8}{|c|}{ Coefficients $^{\mathrm{a}}$} \\
\hline \multirow[t]{2}{*}{ Model } & \multicolumn{2}{|c|}{$\begin{array}{c}\text { Unstandardiz } \\
\text { ed } \\
\text { Coefficients }\end{array}$} & \multirow{2}{*}{\begin{tabular}{|c|}
$\begin{array}{l}\text { Standardized } \\
\text { Coefficients }\end{array}$ \\
Beta
\end{tabular}} & \multirow[t]{2}{*}{$\mathrm{t}$} & \multirow[t]{2}{*}{ Sig. } & \multicolumn{2}{|c|}{$\begin{array}{l}\text { Collinearity } \\
\text { Statistics }\end{array}$} \\
\hline & B & $\begin{array}{l}\text { Std. } \\
\text { Error }\end{array}$ & & & & Tolerance & VIF \\
\hline (Constant) & .004 & .261 & & .015 & .988 & & \\
\hline \begin{tabular}{|l} 
Job \\
Context
\end{tabular} & .254 & .042 & .233 & 6.044 & .000 & .948 & 1.055 \\
\hline $\begin{array}{l}\text { Job } \\
\text { Content }\end{array}$ & .728 & .071 & .645 & 10.299 & .000 & .361 & 2.771 \\
\hline $\begin{array}{l}\text { Personal } \\
\text { Life }\end{array}$ & .010 & .063 & .010 & .160 & .873 & .366 & 2.734 \\
\hline \multicolumn{7}{|l|}{ R-square } & 0.549 \\
\hline \multicolumn{7}{|c|}{ Adjusted R-square } & 0.545 \\
\hline \multicolumn{7}{|l|}{ F-statistic } & 129.507 \\
\hline \multicolumn{7}{|c|}{ Probability of F-statistic } & $.000^{b}$ \\
\hline
\end{tabular}

b. Predictors: (Constant), MeanPL, MeanJ.Ctx, MeanJ.Ctn

\section{V. \\ CONCLUSIONS AND RECOMMENDATION}

There are three research questions and four hypotheses were developed for this study. All of them were answered and tested. The findings strengthen the previous literature that Job Context, Job Content, and Personal Life are predictors towards QWL. However, when assessing the predictors individually, the Personal Life was found not significant. Therefore, further investigation may lead to better understanding on this result. On top of that, it is absolutely clear that, the management of the General Hospital should give special attention to the Job Context and Job Content aspect in improving the QWL.

Special attention also must be given to items measuring the QWL concept since the disagree responses were obvious. For example the item of "The environment in this organization supports a balance between work and personal life" scored 54 disagree responses (17\%). It might deteriorate the QWL level if no action taken for a long term advantage.

\section{Acknowledgment}

Universiti Teknologi MARA Cawangan Terengganu, Kampus Dungun

\section{References}

[1] Rose, R. C., Uli, J., Abdul, M., \& Ng, K. L. (2004). Hospital service quality: A Managerial Challenge. International Journal of Health Care Quality Assurance, 17(3), 146-159. Retrieved from http://www.emeraldinsight.com/doi/abs/10.1108/0952686041053278 4

[2] Butt, H. S., Khan, F., Md. Rasli, A., \& Iqbal, M. J. (2012). Impact Of Work And Physical Environment On Hospital Nurses Commitment, 3(3), 33-43. Retrieved from https://www.researchgate.net/publication/234096971

[3] Sheel, S., Sindhwani, B. K., Goel, S. \& Pathak, S. (2012). Quality Of Work Life, Employee Performance And Career Growth Opportunities: A Literature Review. International Journal of Multidisciplinary Research, 2(2), 291-300. Retrieved from http://zenithresearch.org.in/images/stories/pdf/2012/Feb/ZIJMR/22_ ZEN_VOL2ISSUE2_FEB12.pdf

[4] Battu, N., \& Chakravarthy, G. k. (2014). Quality Of Work Life Of Nurses And Paramedical Staff In Hospitals. International Journal of Business and Administration, 2(4), 200-207. Retrieved from http://ijbarr.com/downloads/2014/vol2-issue4/25.pdf

[5] Nizar, S., Nave, F., \& Matos, F. (2015). The Quality of Working Life Among Nurses in Pediatric Setting. Future Academy www.FutureAcademy.org.uk, 6-14. http://www.futureacademy.org.uk/files/menu_items/other/1j.pdf

[6] Aninkan, D. O. (2014). The Impact of Reward Management and Job Enrichment On Job Satisfaction among Employees In The Ogun State Polytechnics. International Journal of Business and Management Invention, 3(3), 19-26. Retrieved from http://www.ijbmi.org/papers/Vol(3)3/Version-3/C0333019026.pdf

[7] Horst, D. J., Broday, E. E., Bondarick, R., Serpe, L., F., \& Pilatti, L., A. (2014). Quality of work Life and Productivity: An Overview of The Conceptual Framework. International Journal of Managerial Studies and Research 2(5), 87-98. Retrieved from https://www.arcjournals.org/pdfs/ijmsr/v2-i5/11.pdf

[8] Jayakumar, A., \& Kalaiselvi, K. (2012). Quality Of Work Life-An Overview. International Journal of Marketing, Financial Services \& Management Research, 1(10),140-151. Retrieved from http://indianresearchjournals.com/pdf/IJMFSMR/2012/October/12.pd f

[9] Almalki, M. J., FitzGerald, G., \& Clark, M. (2012). Quality Of Work Life Among Primary Health Care Nurses In The Jazan Region, Saudi 
Arabia: A Cross-Sectional Study. Human Resources for Health, 2-13. Retrieved from http://www.human-resourceshealth.com/content/pdf/1478-4491-10-30.pdf

[10] Birjandi, M., Birjandi, H., \& Ataei, M. (2013). The Relationship Between The Quality Of Work Life And Organizational Commitment Of The Employees Of Darab Cement Company: Case Study In Iran. International Journal of Economics, Business and Finance, 1(7), 154-164. Retrieved from http://www.ijebf.com/IJEBF_Vol.\%201,\%20No.\%207,\%20August\% 20\%202013/The\%20relationship\%20between.pdf

[11] Brannick, Michael T., and Edward. L. Levine. (2002). Job Analysis: Methods, Research, and Applications for Human Resource Management in the New Millennium. Retrieved from http://onlinelibrary.wiley.com/doi/10.1177/10384111030412013/abst ract

[12] Kulkarni, P. (2013). A Literature Review On Training \&Development And Quality Of Work Life. Journal of Arts, Science \& Commerce, 4(2), 136-143. Retrieved from http://www.researchersworld.com/vol4/issue2/Paper_20.pdf

[13] Mosadeghrad, A. M. (2013). Quality of Working Life: An Antecedent to Employee Turnover Intention. International Journal of Health Policy and Management, 1(1), 49-58. Retrieved from http://www.tums.ac.ir/1393/01/24/QWL.pdf-mosadeghrad-2014-0413-04-18.pdf

[14] Linguli, L. M. (2013). Influence Of Work Environment On Employees' Quality Of Work life And Commitment At Devki Steel Mills Limited-Ruiru, 1-48. Retrieved from http://erepository.uonbi.ac.ke/handle/11295/58929

[15] Al-Khasawneh, A. L., \& Futa, S. M. (2013). The Relationship between Job Stress and Nurses Performance in the Jordanian Hospitals: A Case Study in King Abdullah The Founder Hospital. Asian Journal of Business Management, 5(2), 267-275. Retrieved from http://maxwellsci.com/print/ajbm/v5-267-275.pdf

[16] Kats, R., \& I.Goldberg, A. (1982). Working Extra Hours: Worker Involvement in the Modern Era. 11(1), 31-34. Retrieved from http://www.emeraldinsight.com/doi/abs/10.1108/eb055451

[17] Afsar, S. T. (2014). Impact of the Quality of Work-life on Organizational Commitment: A Comparative Study on Academicians Working for State and Foundation Universities in Turkey. International Journal of Social Sciences, 3(4), 124-152. Retrieved from http://www.iises.net/download/Soubory/IJOSS/V3N4/pp124152_ijoss_V3N4.pdf

[18] Islam, M. B. (2012). Factors Affecting Quality of Work Life: An Analysis on Employees of Private Limited Companies in Bangladesh. Global Journal of Management and Business Research, 12(18), 23-31. Retrieved from https://globaljournals.org/GJMBR_Volume12/4-Factors-AffectingQuality-of-Work-Life-An.pdf

[19] Das, S. C. (n.d). Factor Affecting Quality Work Life: Empirical Evidence From Indian Sugar Mills. Faculty of Commerce, Banaras Hindu University, 1-26. Retrieved from http://chuka.ac.ke/publications/6620-23556-1-PB.pdf

[20] Nursing Leadership Management \& Leadership Style. (2014). Retrieved from https://www.anac.org/docs/white-papers/2013nursing-leadership---management-leadership-styles.pdf?sfursn=4

[21] Leblebici, D. (2012). Impact Of Workplace Quality On Employee's Productivity: Case Study Of A Bank In Turkey. Journal of Business, Economics \& Finance, 1(1), 38-49. Retrieved from http://sosyalbilimler.okan.edu.tr/media/06/50ed303d150ba0f3500000 06/4-Demet_Leblebici.pdf

[22] Indumathy, R., \& Kamalraj. S. (2012). A Study On Quality Of Work Life Among Workers With Special Reference To Textile Industry In Tirupur District - A Textile Hub. International Journal of Multidisciplinary Research, 2(4), 265-281. Retrieved from http://www.zenithresearch.org.in/images/stories/pdf/2012/April/ZIJ MR/24_ZIJMR_APRIL12_VOL2_ISSUE4.pdf

[23] Gayathiri, R., \& Ramakrishnan, L (2013). Quality of Work Life Linkage with Job Satisfaction and Performance. International Journal of Business and Management Invention, 2(1), 1-8. Retrieved from http://www.ijbmi.org/papers/Vol(2)1/Version_2/A210108.pdf

[24] Sojka, L. (2014). Specification of the Quality of Work Life Characteristics In The Slovak Economic Environment, 46(3), 283-
299.

Retrieved

from

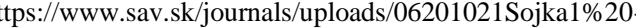

\%20OK.pdf

[25] Moradi, T., Maghaminejad, F., \& Fini, I. A. (2014). Quality of Working Life of Nurses and its Related Factors. 1-6. Retrieved from http://www.ncbi.nlm.nih.gov/pmc/articles/PMC4228533/

[26] Saravani, S. H., \& Abbasi, B. (2013). Investigating The Influence Of Job Rotation On Performance By Considering Skill Variation And Job Satisfaction Of Bank Employees. 473-478. Retrieved from http://webcache.googleusercontent.com/search?q=cache:PtH5Tpt39z EJ:hrcak.srce.hr/file/153018+\&cd=1\&hl=en\&ct=clnk

[27] Bauer, T. (2015). Motivating Employees Through Job Design, 1-3. Retrieved http://www.peoi.org/Courses/Coursesen/orgbeh1/ch/ch6a.html

[28] Nafei, W. A. (2014). Do Job Rotation and Role Stress Affect Job Attitudes? A Study from Egyptian Context. American International Journal of Social Science, 3(1), 94-108. Retrieved from http://www.aijssnet.com/journals/Vol_3_No_1_January_2014/9.pdf

[29] Dabale, W. P., Jagero, N., \& Nyauchi, M. (2014). The Relationship between Training and Employee Performance: The Case of Mutare City Council, Zimbabwe. International Journal of Human Resource Studies, 4(4), 61-72. Retrieved from http://chuka.ac.ke/publications/6620-23556-1-PB.pdf

[30] Nanjundeswaraswamy, T. S., \& Swamy. (2013). Review Of Literature On Quality Of Work life. International Journal for Quality Research, 7(2) 201-214. Retrieved from http://www.ijera.com/papers/Vol2_issue3/GB2310531059.pdf

[31] Heizer, J., Render, B. \& Munson, C. (2017). Operations Management: Sustainability and Supply Chain Management. (12th ed.) United States: Pearson Education Inc.

[32] Taghavi, S., Ebrahimzadeh, F., Bhramzadh, H. A., \& Masoumeh, H. (2014). A study of the relationship between quality of work life and performance effectiveness of high school teachers' in Shirvan. International Journal of Academic Research in Business and Social Sciences, 4(1), 295-301. Retrieved from http://hrmars.com/hrmars_papers/A_study_of_the_relationship_betw een_quality_of_work_life_and_performance_effectiveness_of_high_ school_teachers.pdf

[33] Rai, R., \& Tripathi, S. (2015). A Study on QWL and its effects on Job Performance. Journal of Management Sciences and Technology, 2(2), 33-42. Retrieved from http://www.apeejay.edu/aitsm/journal/docs/issue-feb-

2015/rashmifinalpaper.pdf

[34] Kennedy, J. (2009). The Impact Of Training And Development On Job Performance. 1-66. Retrieved from http://ir.knust.edu.gh/bitstream/123456789/593/1/JOSEPH\%20KEN NEDY.pdf

[35] Hosmani, A. P., Shambhushankar, \& Bindurani, R. (2014). Study on Impact of Quality of Work Life on Job Performance amongst Employees of Secunderabad Division of South Central Railway. Journal of Management Sciences, 3(11), 8-11. Retrieved from http://www.isca.in/IJMS/Archive/v3/i11/2.ISCA-RJMS-2014-85.pdf

[36] Adzei, F. A., \& Atinga, R. A. (2012), Motivation and retention of health workers in Ghana's district hospitals. Journal of Health Organization and Management, 26(4), 467 - 485. Retrieved from http://www.emeraldinsight.com/doi/abs/10.1108/1477726121125153 5

[37] Jelstad , B. (n.d). Job characteristics and its outcomes - A comparative work design study of non-profit and profit organizations. 1-17. Retrieved from http://www.polis.no/Paper/Aarhus05/PJELSTAD.PDF

[38] Hegney, C., Plank, A., \& Parker, V. (2006). Extrinsic and Intrinsic Work Values: Their Impact on Job Satisfaction in Nursing. Journal of Nursing Management, 14(4), 271-281. Rerieved from http://citeseerx.ist.psu.edu/viewdoc/download?doi=10.1.1.484.1201\& rep=rep $1 \&$ type $=$ pdf

[39] Sinha, C. (2012). Factors Affecting Quality Of Work Life: Empirical Evidence From Indian Organizations. Australian Journal of Business and Management Research, 1(11), 31-40. Retrieved from http://ajbmr.com/articlepdf/AJBMR 20_07_4.pdf

[40] Fortune, D. (2006). An Examination of Quality of Work Life And Quality of Care Within a Health Care Setting, 1-114. Retrieved from 
http://citeseerx.ist.psu.edu/viewdoc/download?doi=10.1.1.66.9415\&r ep=rep $1 \&$ type $=$ pdf

[41] Roos, J. H. (2012). Quality Of Work Life In Health Services: Magnetism And Mentorship,1-20. Retrieved from http://www.unisa.ac.za/news/docs/Inaugural.JH-Roos.-

22Augustus.pdf

[42] Raisinghani, M. \& Goswami, R. (2014). Model of Work Life Balance Explaining Relationship Constructs. International Journal of Application or Innovation in Engineering \& Management, 3(2), 4659. Retrieved from http://ijaiem.org/volume3issue2/IJAIEM-201402-17-028.pdf

[43] Mohamad, M., \& Mohamed, W. N. (2012). A Model of Quality of Work Life, Life Satisfaction and Service Quality. Asian Journal of Business Research, 2(2), 38-51. Retrieved from http://www.magscholar.com/joomla/images/docs/ajbr/ajbrv2n2/A\%2 0Model\%20of\%20Quality\%20of\%20Work\%20Life.pdf

[44] Greenhaus, J. H., Collins, K. M., \& Shaw, J. D. (2003). The Relation Between Work-Family Balance And Quality Of Life. Journal of Vocational Behavior. 510-531. Retrieved from http://www.polyu.edu.hk/mm/jason/doc/Greenhaus-CollinsShaw\%202003\%20JVB.pdf

[45] Sekaran U (2006). Research Method for Business: A Skill Building Approach. New Delhi: John Wiley \& Sons. Inc

[46] Hair, J.F., Hult, G.T.M., Ringle, C. M., \& Sarstedt, M. 2014. A Primer on Partial Least Squares Structural Equation Modeling (PLSSEM). USA: SAGE Publications, Inc.

[47] Pallant, J.M. (2010). SPSS Survival Manual. 4th ed., Open University Press. 